\section{KEBIJAKAN NASIONAL TERHADAP \\ PEMBANGUNAN BERWAWASAN LINGKUNGAN}

Oleh: Poerwanti Hadi Pratiwi ${ }^{1}$

\section{Abstracts}

This article is going to discuss about national policy in the development of environment concept, or known as Ecodevelopment. The focus of this article will be more illuminated on the decreasing of causal factor of development in Indonesia.

Ecodevelopment strategy consist of especially elements are community different from others, specific cultural values, live in specific territories, and specific resources too. Because of ecodevelopment strategy goals are reform and develop specific conditions, not create "development" in term GNP (Gross National Product) or another abstraction. Ecodevelopment can be applied in various local ecosystem according cultural and ecology data from specific community.

Now, Indonesia active doing development in all aspect, be up against some problems of ecology acpect. Ecodevelopment policies are approach of resources management, the welfare meaning, responsibility from inter-generation, and factor of problems.

Keywords: Ecodevelopment, National Policy, Environment

\section{A. PENDAHULUAN}

Gagasan mengenai ecodevelopment lahir dalam konferensi PBB mengenai lingkungan pada tahun 1972. pencetusnya pada waktu itu adalah Maurice Strong dan kemudian konsep tersebut dikembangkan dan dipopulerkan oleh Ignacy Sachs, yang mengemukakan definisi tentang ecodevelopmen. Ecodevelopment adalah suatu gaya pembangunan yang dalam setiap kawasan ekologi, membutuhkan solusi khusus bagi masalah tertentu di kawasan tersebut berdasarkan data kultural dan data ekologi serta

${ }^{1}$ Staf Pengajar di Prodi Pendidikan Sosiologi, FISE, UNY kebutuhan jangka panjang dan mendesak. Karena itu, pembangunan berwawasan ekologi dilaksanakan berdasarkan kriteria pembangunan yang dihubungkan dengan setiap kasus tertentu, dan penyesuaian diri terhadap lingkungan memainkan peranan penting. ${ }^{2}$

Pembangunan berwawasan ekologi memerlukan strategi pembangunan yang sangat berbeda dari strategi konvensional dengan unsur universalnya, yaitu: modal, tenaga kerja, investasi, dan lain-lain. Strategi pembangunan berwawasan lingkungan (ekologi), sebaliknya, terdiri atas unsur-unsur yang spesifik, yaitu: kelompok masyarakat tertentu, dengan nilai budaya tertentu, yang hidup dalam kawasan tertentu, dengan sumber daya tertentu pula. Oleh karena itu, tujuan strategi pembangunan berwawasan ekologi adalah memperbaiki dan mengembangkan situasi spesifik itu, bukan menciptakan "pembangunan" dalam pengertian GNP atau abstraksi lainnya.

Pembangunan berwawasan ekologi dapat diterapkan pada berbagai ekosistem local dan hanya dengan jalan inilah sifat abstraksi konsep tersebut diganti oleh pemahaman konkret mengenai implikasinya. Karena itu, mari kita hubungkan pembahasan mengenai pembangunan berwawasan ekologi dengan praksis (penerapan) konsep tersebut di Indonesia.

Indonesia sejak beberapa dasawarsa terakhir sangat giat melaksanakan pembangunan di segala bidang, dalam menghadapi berbagai permasalahan di bidang lingkungan hidup. Secara umum permasalahan lingkungan hidup di Indonesia terdapat 5 hal pokok, yaitu: pencemaran (pollution), pemanfaatan alam secara tidak terkendali, kepadatan penduduk (population bomb), menurunnya populasi fauna, dan ketidakseimbangan ekosistem-ekosistem

1. Pencemaran (pollution)

Pencemaran yang kini dirasakan berbarengan erat dengan teknologi mekanisme, industrialisasi, serta pola-pola hidup yang mewah dan konsumtif. Masalah pencemaran muncul bilamana suatu zat atau energi dengan tingkat

2 Sachs (1974) dalam Hettne, 2001: 335.

DIMENSIA, Volume 2, No. 1, Maret 2008 
konsentrasi yang sedemikian rupa hingga dapat merubah kondisi lingkungan, baik secara langsung atau tidak langsung dan pada akhirnya lingkungan tidak dapat lagi berfungsi sebagaimana mestinya.

Timbulnya pencemaran tentu saja erat kaitannya dengan berbagai aktivitas manusia, antara lain:

a. Kegiatan-kegiatan industri, dalam bentuk limbah, zat-zat buangan berbahaya seperti logam-logam berat, zat radioaktif, air buangan panas (thermal water waste). Juga dalam bentuk kepulan asap (smog), kebisingan dan lainlain

b. Kegiatan pertambangan, berupa terjadinya kerusakan instalasi, pencemaran buangan-buangan penambangan, pencemaran udara dan rusaknya lahan-lahan bekas pertambangan

c. Kegiatan transportal, berupa asap, naiknya suhu udara kota, kebisingan dari kendaraan bermotor, tumpahantumpahan bahan baker terutama minyak bumi dari kapalkapal tanker, dan lain-lain

d. Kegiatan pertanian, terutama akibat residu pemakaian zat-zat kimia yang memberantas binatang-binatang dan tumbuhan-tumbuhan penggangu, seperti: insektisida, pestisida, herbisida, atau fungisida. Demikian pula pemakaian pupuk organik dan lain-lain

2. Pemanfaatan alam secara tidak terkendali

Masalah berikut ialah rusaknya tata lingkungan alami. Hal ini merupakan dampak dari tingkah laku manusia dalam mengeksploitasi dan menggunakan sumber-sumber daya alam secara tidak seimbang (over stress). Disadari atau tidak, kenyataan ini dapat dilihat lewat praktek-praktek masyarakat seperti penebasan hutan sampai gundul, pemanfaatan ekosistem pantai (esturia, mangrove, karang-karang pantai, pasir, kerikil, atau timah), penangkapan ikan laut sampai melampaui batas konservasinya, penggunaan alat-alat beracun dan peledak untuk penangkap ikan, berburu binatang-binatang liar, pertanian dengan sistem lahan berpindah.

Masalah ini merupakan dampak yang kait-mengait satu dengan lainnya oleh kenyataan-kenyataan berikut ini antara lain: tingkat pertumbuhan penduduk yang lebih mengungguli pertumbuhan kebutuhan dasar dan kebutuhan lainnya, perkembangan kemajuan di bidang ilmu pengetahuan dan teknologi, peningkatan taraf hidup konsumerisme, masalah keterbatasan alam untuk diolah terutama sumber-sumber daya yang bersifat renewable (sumber-sumber daya yang tidak dapat diperbaharui), pengangguran, dan lain-lain. Tetapi menurut Prof. Sumitro Djojohadikusumo masalah yang paling pokok kini dihadapi manusia terutama di negara berkembang ialah masalah kemiskinan pangan.

3. Kepadatan penduduk

Kepadatan penduduk lazim disebut "ledakan penduduk" (population bomb). Pertambahan penduduk makin lama makin meningkat hingga akhirnya memadati muka bumi. Hal ini kemudian justru merupakan rentetan-rentetan masalah-masalah besar yang membentuk sistem lingkungan, dan juga karena setiap manusia tidak lepas dari kebutuhan mulai dari yang pokok sampai kebutuhan pelengkap. Sedangkan semua faktor tersebut baru dapat dipenuhi bila siklus dan cadangan-cadangan sumber daya alam masih mampu dan mencukupi, tetapi akan lain jadinya jika pertambahan penduduk kian melewati batas siklus ataupun jumlah cadangan sumber-sumber kebutuhan. Andaikata kondisi perkembangan demikian tidak ditata secara terencana maka pada saatnya akan terjadi suatu masa krisis.

4. Menurunnya populasi fauna

Menurunnya populasi makhluk hidup (terutama binatang-binatang liar) selain yang untuk mencukupi kebutuhan berupa tindakan berburu, namun juga banyak berkaitan dengan kegiatan-kegiatan lain yang bisa 
menganggu perkembangbiakan (populasi) dan merusak habitat binatang-binatang tersebut.

Lewat media massa, kita dapat mengetahui adanya gajah yang secara bergerombol mengobrak-abrik dan menghancurkan rumah-rumah penduduk, harimau yang membinasakan beberapa orang peladang, dan lainnya. Timbulnya kenyataan ini sebagai akibat pengaruh hutan yang sudah gersang sehingga habitat untuk hewan-hewan tersebut sudah tidak ada lagi. Populasi fauna pun kian langka dan menuju pada kepunahan.

Aktivitas lain juga berupa penyemprotan hama melalui obat pembasmi pestisida dan semacamnya seperti sudah disebutkan di atas. Memang penyemprotan dengan cara itu cukup praktis untuk membunuh serangga dan hamahama yang merusak tanamanatau mengganggu ketenteraman. Pemakaian DDT dan semacamnya (eldrin, dieldrin, chlordane, dan lain-lain) yang peristen dan sukar terurai akan merembes ke dalam rantai-rantai makanan, yang selanjutnya akan mempengaruhi mahkluk-makhluk lain. Disini timbul pula dampak yang tidak disadari. Tindakan pembasmian tersebut ternyata juga telah mengakibatkan makhluk-makhluk lain yang bukan menjadi sasaran ikut terbasmi, padahal makhluk-makhluk tersebut berfungsi sebagai predator, yaitu binatang pemangsa yang bermanfaat mengontrol populasi binatang secara efektif dan banyak manfaatnya bagi kehidupan manusia.

5. Ketidakseimbangan ekosistem-ekosistem

Masalah lingkungan tidak saja terbatas pada masalah biofisik, tetapi juga pada lingkungan sosial (ekosistem sosial), misalnya yang dapat dirasakan berupa bergesernya sistem nilai seperti nilai kegotong-royongan, etika, serta nilai-nilai budaya lainnya.

Bertumpunya pembangunan di kota mengakibatkan terjadinya kesenjangan kesejahteraan, sehingga banyak penduduk desa yang mengadakan urbanisasi ke kota Masalah yang ditimbulkan kemudian adalah padatnya penduduk di kota dan pada tahap lebih lanjut akan menambah permasalahan-permasalahan perkotaan seperti timbulnya pengangguran, gelandangan, meningkatnya kriminalitas, terganggunya kelancaran lalu lintas, rendahnya mutu kesehatan lingkungan, dan sebagainya

Masyarakat nelayan yang pada umumnya miskin semakin dilanda kemiskinan dan keresahan karena adanya ketidakseimbangan ekosistem sosial. Apabila di dalam lingkungan tersebut tidak tercipta suatu keharmonisan, maka dapat menimbulkan keresahan sosial bagi masyarakat nelayan, misalnya sistem pemilik trawl (pukat harimau) yang diizinkan beroperasi. Trawl dengan sistem teknologi yang canggih dan dengan kapasitas (catching capacity) yang bersifat raksasa, memang memakmurkan beberapa gelintir orang. Tetapi sebaliknya semakin menerjang kehidupan sebagian besar masyarakat nelayan. Adanya Kep.Pres No 39 Tahun 1980 tentang pelarangan penggunaan trawl untuk beroperasi di perairan Indonesia, dapat dianggap sebagai salah satu bentuk upaya pelestarian lingkungan hidup.

\section{B. KEBIJAKSANAAN DALAM \\ BERWAWASAN LINGKUNGAN}

Hasil pembangunan yang terpenting adalah tumbuhnya aspirasi baru mengenai kesejahteraan hidup penduduk. Ada beberapa indikator yang digunakan untuk mengukur tingkat kesejahteraan penduduk, mulai dari pemenuhan kebutuhan pokok berupa sandang dan pangan, pelayanan kesehatan, tersedianya lapangan pekerjaan dan perumahan yang layak, kesempatan mengenyam pendidikan, adanya jaminan sosial, hingga pada kesempatan maju yang sama dalam lingkungan hidup dan hukum yang adil dan berkualitas.

Disini terlihat bahwa makna yang terkandung dalam "pembangunan" jauh lebih luas daripada hanya sekedar kenaikan 
pendapatan nasional. Pembangunan berwawasan lingkungan mengandung makna mengolah sumber daya untuk meningkatkan kesejahteraan masa kini, tanpa mengurangi kemampuan generasi masa depan mengolah sumber daya untuk meningkatkan kesejahteraannya. Untuk itu perlu dikaji lebih lanjut hal-hal berikut ini:

1. Pendekatan dalam mengelola sumber daya Sumber daya dibagi atas:

a. Sumber daya alam

1) Pengelolaan sumber daya alam yang dapat diperbaharui (renewable resources), dengan pendekatan "mengolah sumber daya alam ini tanpa mengurangi kemampuan sumber daya untuk memperbaharui diri supaya bisa tetap berfungsi

2) Pengelolaan sumber daya alam yang tidak dapat diperbaharui (unrenewable resources), dengan pendekatan "teknologi yang digunakan agar bisa menghasilkan dan mengadakan daur ulang"

b. Sumber daya manusia

1) Nilai kuantitatif, dengan mempertimbangkan jumlah pertumbuhan dan pola persebaran

2) Nilai kualitatif, dengan melihat kemampuan kreatif yang dimiliki dan produktivitas yang dihasilkan

Pentingnya pendekatan dalam pengelolaan sumber daya ini karena "pembangunan" berarti mengolah sumber daya, dan dalam mengolah sumber daya dibutuhkan pengetahuan mengenai lingkungan alam, lingkungan buatan manusia dan lingkungan sosial. Dalam pengelolaan sumber daya untuk pembangunan inilah maka akan timbul permasalahanpermasalahan seperti yang telah disebutkan diatas.

2. Makna kesejahteraan

Apabila keperluan untuk kelangsungan hidup sudah tercapai, seperti terpenuhinya sembilan bahan kebutuhan pokok, maka kebutuhan manusia makin meluas, mencakup berbagai segi kesejahteraan dengan muatan kuantitatif dan kualitatif. Dalam mencapai kesejahteraan ini, berbagai dimensi tidak sepenuhnya dapat dipenuhi oleh mekanisme pasar, yang mempengaruhialokasi sumber daya, seperti:

a) Segi kualitas lingkungan alam, yaitu seberapa besar nilai sumber daya yang habis terkuras?

b) Segi kualitas lingkungan buatan, yaitu seberapa banyak nilai air, udara, dan ruang yang tercemar?

c) Segi kualitas sosial, yaitu bagaimana kebutuhan rakyat miskin bisa dipenuhi apabila ia tidak memiliki sumber daya akibat kemiskinan?

Jawaban atas pertanyaan-pertanyaan ini membutuhkan intervensi pemerinta untuk menanggulanginya, baik dengan mengusahakannya secara langsung maupun dengan mengoreksi mekanisme pasar sehingga menghasilkan isi dan makna kesejahteraan mencakup segi kualitas lingkungan alam, lingkungan buatan manusia dan kualitas lingkungan sosial.

3. Tanggung jawab antar generasi

Pembangunan berwawasan lingkungan memuat makna berkesinambungan. Dalam proses perubahan yang sedang berlangsung, diperlukan adanya pengelolaan sumber daya yang mengarah pada investasi, orientasi, pengembangan teknologi dan perubahan kelembagaan yang berjalan seiring dengan keperluan untuk memenuhi kesejahteraan generasi masa kini dan generasi masa depan.

Untuk mencapai makna kesinambungan itu, perlu ditopang oleh perencanaan pembangunan yang tepat dan kemampuan sistem ekonomi dalam mengolah sumber daya masa kini. Selain itu juga perlu dipersiapkan kebutuhan generasi masa depan beserta dengan sumber daya yang dibutuhkan dan pemilihan tingkat teknologi yang tepat.

4. Faktor kendala

Terdapat berbagai fakor kendala yang membatasi usaha pembangunan berwawasan lingkungan, antara lain: 
a) Perkembangan teknologi masa kini banyak yang didasarkan pada kebutuhan yang berorientasi pasar dan tidak memperhatikan dimensi lingkungan dan kepentingan masa depan. Contohnya adalah perkembangan energi nuklir yang masih belum sanggup menjawab berbagai pertanyaan lingkungan yang berkaitan dengan resiko yang akan dihadapi generasi masa depan. Hal ini mendorong keharusan untuk menguji ulang kemampuan dan posisi teknologi. Teknologi belum sanggup menciptakan biosphere tambahan atau biosphere baru sehingga perkembangan teknologi harus tertuju pada usaha untuk mengurangi dampak negatif perilaku manusia terhadap biosphere

b) Kemampuan organisasi kemasyarakatan menanggapi tantangan persoalan baru yang ditimbulkan oleh pertambahan penduduk, semakin kompleks dan meningkatnya kebutuhan masyarakat

c) Terbatasnya kemampuan lingkungan untuk mendukung jumlah dan permintaan kebutuhan manusia yang semakin meningkat

\section{PENUTUP}

Dengan meningkatnya makna perluasan wawasan pembangunan dengan pertimbangan lingkungan, maka hambatan pokok dalam pengembangan pola pembangunan ini adalah bahwa unsur-unsur yang ada tidak tertampung dalam arus pemikiran ekonomi. Banyaknya unsur-unsur lingkungan yang tidak tertampung oleh mekanisme pasar ini menyebabkan "lingkungan" jauh dari perhitungan para penyusun kebijakan pembangunan.

Pembangunan ekonomi masih menjadi tantangan pokok di masa depan, jadi wajar bila diusahakan agar wawasan lingkungan diintegrasikan ke dalam wawasan ekonomi. Dalam hubungan ini, perlu dikembangkan instrumen analisis ekonomi lingkungan yang memuat masalah pengolahan sumber-sumber daya agar permasalahan lingkungan yang timbul semakin berkurang.

Berbagai sumber daya yang memerlukan prioritas perhatian khusus dalam pola pembangunan berwawasan lingkungan adalah sumber-sumber daya: air, tanah, hutan, energi, dan manusia. Berbagai masalah lingkungan yang timbul bertumpu pada lima sumber daya tersebut, seperti masalah-masalah kekeringan, banjir, erosi, kerusakan hutan, perubahan suhu, kerusakan keanekaragaman biologi, pencemaran, keracunan, dan berbagai kerusakan lingkungan lainnya. Untuk menanggulangi berbagai masalah lingkungan ini perlu diusahakan pengembangan sumber-sumber daya air, tanah, hutan, energi, dan manusia dengan pertimbangan lingkungan yang terintegrasi ke dalam instrumen analisis ekonomi dan teknologi.

Pertimbangan lingkungan yang dimaksud mencakup segisegi lingkungan alam, lingkungan buatan manusia, dan lingkungan sosial. Instrumen analisis ekonomi dengan wawasan lingkungan yang perlu dikembangkan adalah yang relevan berkaitan dengan pengolahan kelima sumber daya strategis di atas. Usaha ini tidak hanya berhenti pada pengembangan instrument analisis, tetapi juga harus bermuara pada implementasi instrumen analisis tersebut dalam kebijakan-kebijakan yang diambil pemerintah dalam perencanaan pembangunan yang berwawasan lingkungan.

Peran pemerintah dalam perencanaan pembangunan di negara-negara berkembang sangat besar melalui penggunaan:

1. Seperangkat instrumen kebijakan dalam menetapkan sumber pendapatan pemerintah, missal: pajak, bea cukai, dan pungutan

2. Seperangkat instrumen kebijakan dalam menetapkan sumber pengeluaran pemerintah seperti anggaran rutin dan pembangunan pemerintah pusat dan pemerintah daerah

3. Kegiatan berproduksi langsung melalui Badan Usaha Milik Negara (BUMN)

4. Hak dan kewajiban dalam menetapkan peraturan

5. Kemampuan persuasi melalui penerangan dan pendidikan 
Meskipun peran pemerintah cukup penting, namun pelaksanaan pembangunan umumnya berada di tangan masyarakat yang terintegrasi dalam: organisasi politik dengan motivasi politik, organisasi ekonomi dengan motivasi ekonomi, organisasi sosial dengan motivasi sosial, dan organisasi swadaya masyarakat dengan motivasi kemanusiaan. Dalam pola pembangunan berwawasan lingkunga perlu dikembangkan iklim yang mendorong masyarakat melaksanakan hak untuk berperan serta melalui jalan politik, ekonomi, dan swadaya masyarakat dan bersama dengan pemerintah menumbuhkan kebijaksanaan pemerintah untuk:

1. Mengoreksi mekanisme pasar agar memuat permasalahan lingkungan dalam lingkungan

2. Menumbuhkan segi kualitatif pembangunan yang tidak bisa dicapai melalui tindakan ekonomi biasa

3. Menciptakan iklim usaha yang merangsang pertumbuhan organisasi-organisasi politik, ekonomi, sosial dan swadaya dalam arus motivasinya masing-masing

Pada hakikatnya, masalah lingkungan bersifat kait-mengait dalam hubungan lintas sektor, maka proses pelaksanaan kegiatan pembangunan berwawasan lingkungan harus berada sedekat mungkin dengan lokasi kegiatan agar dapat berjalan dengan efektif. Ini berarti, dikembangkannya proses desentralisasi dan debirokratisasi dalam pelaksanaan pembangunan ditujukan untuk memberikan lebih banyak peluang kepada masyarakat untuk mengembangkan prakarsa dan daya kreativitasnya.

Sejak tahun 2000, proses pembangunan di Indonesia dipengaruhi oleh banyak faktor, seperti meningkatnya sumber daya dalam negeri, menanggulangi tekanan pada sumber daya luar negeri, merobak struktur ekonomi berimbang, menanggapi akibat pertambahan penduduk Indonesia yang terus meningkat, dan mengembangkan kualitas hidup dengan tingkat kemiskinan yang berkurang dalam masyarakat yang berkeadilan social.

Faktor yang yang beraneka macam itu memerlukan sumber daya alam dan sumber daya manusia yang dikelola dalam pola pembangunan berwawasan lingkungan, agar cita-cita jangka panjang bisa tercapai untuk meningkatkan kesejahteraan rakyat tidak hanya untuk generasi masa kini, tetapi juga untuk generasi masa depan Kesemuanya itu membutuhkan peran aktif dan perhatian dari pemerintah pusat maupunpemerintah daerah, swasta, LSM, dan masyarakat luas. Keberhasilan pembangunan secara keseluruhan tentu tidak harus diikuti oleh kerusakan alam yang kita lindungi.

\section{Daftar Pustaka}

Arief Budiman. Teori Pembangunan Dunia Ketiga. Jakarta: Gramedia Pustaka Utama. 2000.

Emil Salim. Lingkungan Hidup dan Pembangunan. Jakarta: Mutiara. 1981.

Hettne, Bjorn. Teori Pembangunan dan Tiga Dunia. Jakarta: Gramedia. 2001.

Mansour Fakih. Runtuhnya Teori Pembangunan dan Globalisasi Yogyakarta: Insist Press dan Pustaka Pelajar. 2002.

Sumitro Djojohadikusumo. Indonesia dalam Perkembangan Dunia, Kini, dan Masa yang Akan Datang. Jakarta: LP3ES 1981. 